\title{
Energy Conversion from Aluminium and Phosphate rich solution via ZnO Activation of Aluminium
}

\author{
G. Slaughter, Joshua Sunday and Brian Stevens
}

Bioelectronics Laboratory, Department of Computer Science and Electrical Engineering, University of Maryland Baltimore County, Baltimore, MD 21250, United States.

Electrochemical power sources have motivated intense research efforts in the development of alternative 'green' power s ources for ultra-low powered bioelectronic devices. Biofuel cells employ immobilized enzymes to convert the available chemical energy of organic fuels directly into electricity. However, biofuel cells are limited by short lifetime due to enzyme inactiv ation and frequent need to incorporate mediators to shuttle electrons to the final electron acceptor. In this context, other electrochemical power sources are necessary in energy conversion and storage device applications. Here we report on the fabrication and characterization of a membrane-free aluminium/phosphate cell based on the activation of aluminium (Al) using $\mathrm{ZnO}$ nanocrystal in an $\mathrm{Al} /$ phosphate cell as a 'green' alternative to the traditional enzymatic biofuel cells. The hybrid cell operates in neutral phosphate buffer solution and physiological saline buffer. The ZnO modifier in the phosphate rich electrolyte activated the pitting of $\mathrm{Al}$ resulting in the production of hydrogen, as the reducing agent for the reduction of $\mathrm{H}_{2} \mathrm{PO}_{4}{ }^{-}$ ions to $\mathrm{HPO}_{3}{ }^{2-}$ ions at a formal potential of $-0.250 \mathrm{~V}$ vs. Ag/AgCl. Specifically, the fabricated cell operating in phosphate buffer and physiological saline buffer exhibit an open-circuit voltage of $0.810 \mathrm{~V}$ and $0.751 \mathrm{~V}$ and delivered a maximum power density of $0.225 \mathrm{~mW} \mathrm{~cm}^{-2}$ and $1.77 \mathrm{~mW} \mathrm{~cm}^{-2}$, respectively. Our results demonstrate the feasibility of generating electricity by activating Al as anodic material in a hybrid cell supplied with phosphate rich electrolyte. Our approach simplifies the construction and operation of the electrochemical power source as a novel "green" alternative to the current anodic substrates used in enzymatic biofuel cells for low power bioelectronics applications .

Keywords: Oxides, nanostructures, sol-gel growth, atomic force microscopy

Correspondence and requests for materials should be addressed to G. Slaughter (gslaught@umbc.edu)

\section{Introduction}

Enzymatic biofuel cells employ enzymes as biocatalyst to achieve electrocatalytic oxidation of organic fuel and reduction of oxygen, thereby converting the chemical energy stored in fuel into bioelectricity via redox reactions [1-6] from complex media. The most common biocatalysts employed in glucose biofuel cells are glucose oxidase, glucose dehydrogenase, laccase and bilirubin oxidase [7-9]. These enzymatic based glucose biofuel cells have been proposed as promising 'green' alternative energy source that can sustain the energy demand for bioelectronic devices and small portable electronic devices requiring low power density batteries [8, 10-12]. Although glucose dehydrogenase is the most frequently used enzyme in biofuel cells, it requires the immobilization of $\mathrm{NAD}^{+}$ cofactor. The co-immobilization of $\mathrm{NAD}^{+}$cofactor requires the utilization of complex procedure [13], which limits its application in bioelectronic devices [14]. Thus, in order to achieve kinetically preferential electron transfer, $\mathrm{O}_{2}$ dependent and $\mathrm{NAD}^{+}$dependent enzymatic biofuel cells must employ complex multimolecular arrangement in the fabrication of the cells. These multimolecular ensembles are not readily adaptable for batch fabrication and are insufficient to provide the long-term power that bio-implantable electronic devices require. Moreover, current biofuel cells still rely on the immobilization of biocatalyst on low-cost anodic and cathodic materials that are good electrical conductors, such as carbon nanotubes [15-18] and nanowires [9]. Nevertheless, these enzymatic based biofuel cells are still limited by the short lifetimes of the enzymes due to the denaturation and desorption of the enzymes. This further leads to the instability of the biofuel cell overtime.

Therefore, the generation of energy via novel non-enzymatic anodic substrates is of great importance because of their potential applications in realizing stable source of energy for powering bioelectronic devices. The use of metallic aluminium (Al) in hybrid cell systems eliminate the need for complex and complicated enzyme immobilization strategy, the limitation presented by enzyme inactivity, and the limited power output in enzymatic based biofuel cell systems. The investigation of the activation of $\mathrm{Al}$ in physiological saline buffer is an attractive area in energy conversion applications in order to further improve the performance of electrochemical power sources for ultra-low power implantable bioelectronic devices. Although $\mathrm{Al}$ is highly reactive, it is protected by a surface layer of inert transparent $\mathrm{Al}_{2} \mathrm{O}_{3}$ film (3-6 nm thick) that forms immediately upon exposure to air and/ or water, thereby providing excellent corrosion resistance [19-20]. However, Al will react with aqueous alkaline and acidic solutions to generate hydrogen [21-27] and various anions such as, $\mathrm{Cl}$ - and gluconate anions have been shown to induce pitting corrosion of $\mathrm{Al}$ in water [25-29]. The use of these anions permit the direct reaction of $\mathrm{Al}$ and water to generate hydrogen gas under ambient conditions, which can be used in the development of hydrogen fuel cells [30]. Here pitting corrosion is employed to activate $\mathrm{Al}$ and employ the product, hydrogen, as a reducer in a hybrid aluminium/phosphate cell system. 
Aluminium has been extensively researched as an electrode material because of its geological abundance, strong reducing capability $\left(\mathrm{E}^{\circ}\right.$ $=-1.662 \mathrm{~V}$ ), high specific energy density, low cost, environmentally benign reactions and recyclable aluminium hydroxide byproduct [31-35]. In addition to the above studies using alkaline, acidic or pure water solution for pitting corrosion of $\mathrm{Al}$, there are no reports in the literature using phosphate rich electrolyte in combination with $\mathrm{ZnO}$ nanocrystal modifiers to activate $\mathrm{Al}$. In this work we characterize the activation of $\mathrm{Al}$ anode using $\mathrm{ZnO}$ nanocrystal modifier in phosphate rich electrolyte for aluminium/phosphate cell. This study demonstrates that $\mathrm{ZnO}$ nanocrystals could be used as modifiers on $\mathrm{Al}$ foil for the production of hydrogen and electricity in the presence of phosphate buffer or physiological saline buffer through a pitting corrosion originating from point defects [36]. Furthermore, we demonstrate that the pitting of $\mathrm{Al}$ results in the production of hydrogen that acts as the reducing agent for the reduction of $\mathrm{H}_{2} \mathrm{PO}_{4}^{-}$ions to $\mathrm{HPO}_{3}{ }^{2-}$ ions for use in aluminium/phosphate cell.

\section{Results and discussion}

\section{Effect of ZnO Modifier}

The final $\mathrm{ZnO}$ seed layers prepared via sol-gel and dip-coating techniques can be described as films of white nanocrystals on the $\mathrm{Al} / \mathrm{Au}$ support substrate. To confirm this, atomic force microscopy (AFM) was performed to reveal the surface topography of the thin $\mathrm{ZnO}$ layer on $\mathrm{Al} / \mathrm{Au}$ support and bare $\mathrm{Al} / \mathrm{Au}$ and to measure their roughness. The AFM images presented in Figure 1A shows the formation of $\mathrm{ZnO}$ nanocrystal films that are distributed all over the surface of the electrode, suggesting homogenously dispersed $\mathrm{ZnO}$ nanocrystals on the $\mathrm{Al} / \mathrm{Au}$ support. In addition, the root mean square (RMS) roughness parameter value for $\mathrm{Al} / \mathrm{Au}$ was $7.68 \mathrm{~nm}$ and 62.2 $\mathrm{nm}$ for $\mathrm{Al} / \mathrm{Au} / \mathrm{ZnO}$. The surface of the $\mathrm{Al} / \mathrm{Au} / \mathrm{ZnO}$ is much rougher than the $\mathrm{Al} / \mathrm{Au}$ substrate. The annealing of the $\mathrm{ZnO}$ resulted in the formation of these networked nanostructure films on the electrode surface. Thereby, nanostructuring the $\mathrm{Al}$ with $\mathrm{ZnO}$ transforms the relatively smooth $\mathrm{Al} / \mathrm{Au}$ surface into the fully roughened electrically connected assembly of $\mathrm{ZnO}$. This nanostructured surface allows significantly more $\mathrm{Zn}^{2+}$ to be plugged in by the electrode surface and, as a result, leading to significant increase of the $\mathrm{Al} / \mathrm{Al}^{3+}$ oxidation via pitting mechanism originating from the defect site to overcome the thin oxide film on the Al substrate.

To confirm the formation of pitting corrosion on the Al substrate in phosphate rich electrolyte, experiments with $\mathrm{Al}$ without $\mathrm{ZnO}$ modifier (bare $\mathrm{Al})$ and with $\mathrm{ZnO}(\mathrm{Al} / \mathrm{Au} / \mathrm{ZnO})$ were carried out. The scanning electron microscopy (SEM) micrographs in Figure 1B shows that the bare $\mathrm{Al}$ exhibits a smooth morphology and many mechanical scratches. The bare $\mathrm{Al}$ after being in contact with phosphate rich electrolyte does not show any significant sign of corrosion. On the other hand, the $\mathrm{ZnO}$ modifier on the $\mathrm{Al}$ substrate consist of densely packed nanometer-sized grains with mean grain size of approximately $22 \pm 3 \mathrm{~nm}$ in diameter. It was observed that the byproduct $\mathrm{Al}(\mathrm{OH})_{3}$ forms only on the $\mathrm{ZnO}$ modified $\mathrm{Al}$ substrate during discharging in phosphate electrolyte. This suggest that the uniform hydrothermal growth of $\mathrm{ZnO}$ nanocrystal over the surface of $\mathrm{Al}$ appear to have worn out the initial passive $\mathrm{Al}_{2} \mathrm{O}_{3}$ layer and thereby enabling the reaction of hydrogen generation from $\mathrm{Al}$ in reaction (1).

$$
2 \mathrm{Al}+6 \mathrm{H}_{2} \mathrm{O} \rightarrow 2 \mathrm{Al}(\mathrm{OH})_{3}+3 \mathrm{H}_{2}
$$

It is clear that the oxidation of metallic $\mathrm{Al}$ in water is thermodynamically favourable reaction that results in the production of hydrogen and $\mathrm{Al}(\mathrm{OH})_{3}$ [37]. In contrast, there were no notable changes in the structural morphology of the Al substrate after discharging in phosphate buffer, indicating that the thin $\mathrm{Al}_{2} \mathrm{O}_{3}$ film on the $\mathrm{Al}$ substrate without $\mathrm{ZnO}$ modifier provides corrosion protection of the $\mathrm{Al}$ surface by preventing oxygen and anion transport to the metal surface, which is consistent with the literature reports ${ }^{19-20,36}$. Thereby, the $\mathrm{ZnO}$ modifier aides in the corrosion of metallic $\mathrm{Al}$ to generate $\mathrm{Al}(\mathrm{OH})_{3}$ film and hydrogen gas on the surface of the Al anode in phosphate electrolyte. Discharging in phosphate buffer solution causes the formation of smaller $\mathrm{Al}(\mathrm{OH})_{3}$ grains and promotes a more compact and uniform coating, which may further lead to better corrosion protection. Another observation is that there was a noticeable change in the microstructure of the $\mathrm{Al}(\mathrm{OH})_{3}$ formed in physiological saline buffer. It exhibited blocks of standing flakes surrounded by particles. This suggests that the presence of $\mathrm{Cl}^{-}$ions in the physiological saline buffer can readily transport through the oxide film during pitting corrosion [38] and the $\mathrm{H}_{2} \mathrm{PO}_{4} / \mathrm{HPO}_{3}{ }^{2-}$ anions in the buffer solution react with the solid phase surfaces of $\mathrm{ZnO}$ nanocrystals by adsorption and precipitation [39]. This further indicates that in the presence of phosphate, reactions such as $\mathrm{Zn}^{2+}$ release from $\mathrm{ZnO}$ nanocrystals and the adsorption and precipitation of $\mathrm{HPO}_{3}{ }^{2-}$ induced the microstructural transformation of the $\mathrm{Al}(\mathrm{OH})_{3}$ layer to form $\mathrm{Al}(\mathrm{OH})_{3}$ and $\mathrm{ZnHPO}_{3}$ composite. As the discharge time increases, the corrosion below the oxide film at the defect sites grows and new sites start pitting. Subsequently, the pressure created from the evolution of hydrogen causes the already formed $\mathrm{Al}(\mathrm{OH})_{3}$ and $\mathrm{ZnHPO}_{3}$ composite to detach from the $\mathrm{Al}$ substrate followed by the formation of new $\mathrm{Al}_{2} \mathrm{O}_{3}$ film on top of the Al. The reaction byproduct, $\mathrm{Al}(\mathrm{OH})_{3}$ and $\mathrm{ZnHPO}_{3}$ amorphous composite was confirmed by NMR, EDX and XPS.

\section{Characterization of Reaction Byproducts}

The chemical structure of $\mathrm{Al}(\mathrm{OH})_{3}$ and $\mathrm{ZnHPO}_{3}$ were confirmed by the ${ }^{1} \mathrm{H}$ NMR and ${ }^{31} \mathrm{P}$ NMR. As can be seen in Figures $2 \mathrm{~A}$, only a single peak at 0.72 and $6.1 \mathrm{ppm}$ was found for potassium phosphate buffer and the $\mathrm{Al}(\mathrm{OH})_{3}$ and $\mathrm{ZnHPO}_{3}$ composite byproduct in the ${ }^{31} \mathrm{P}$ NMR spectra, respectively. The singlet at $6.1 \mathrm{ppm}$ is attributed to zinc phosphite, which is in agreement with the literature assignment [40]. The ${ }^{1} \mathrm{H}$ NMR exhibits a singlet and a multiplet centered at 4.7 ppm for proton site associated with phosphates for potassium phosphate and the $\mathrm{Al}(\mathrm{OH})_{3}$ and $\mathrm{ZnHPO}_{3}$ composite, respectively. The singlet observed at 4.1 and $5.2 \mathrm{ppm}$ is attributed to the $\mathrm{Al}-\mathrm{OH}$ proton sites of $\mathrm{Al}(\mathrm{OH})_{3}$ and the peak at 6.0 is associated with phosphites for $\mathrm{ZnHPO}_{3}$. In addition, similar results were obtained for the electrolyte, with a singlet and a multiplet centered at $4.7 \mathrm{ppm}$, thereby suggesting the migration or detachment of the amorphous byproduct from the electrode surface into the electrolyte. Moreover, trace amounts of $\mathrm{Au}$ were not present in the resulting electrolyte. These results are consistent with the literature reports [41-45].

X-ray photoelectron spectra (XPS) of the byproduct obtained from the $\mathrm{Al} / \mathrm{Au} / \mathrm{ZnO}$ anode after discharging in physiological saline buffer were collected to confirm the formation of $\mathrm{Al}(\mathrm{OH})_{3}$ and $\mathrm{ZnHPO}_{3}$. The XPS results showed distinct aluminium, zinc, oxygen, and phosphorous peaks (Figure 2B). These results suggest the formation of the protective $\mathrm{Al}(\mathrm{OH})_{3}$ and $\mathrm{ZnHPO}_{3}$ composite with $\mathrm{Zn} 2 p, \mathrm{O} 1 s$, $\mathrm{P} 2 p, \mathrm{~A} 12 s$ and $\mathrm{A} 12 p$ at binding energies 1022.05, 531.90, 131.10, 119.60 and $73.9 \mathrm{eV}$, respectively, are attributed to the formation of $\mathrm{ZnHPO}_{3}$ and $\mathrm{Al}(\mathrm{OH})_{3}$ [46-47]. The $\mathrm{C} 1 s$ signal signifies the presence of air-borne contamination. Quantitative XPS analysis showed the 
$\mathrm{Zn} / \mathrm{P}$ atomic ratio to be $\sim 0.5$, which was not close to the 1.5 expected for zinc phosphate crystals. This lower $\mathrm{Zn} / \mathrm{P}$ value indicates the film is amorphous.

To reveal the trace elements in the $\mathrm{Al}(\mathrm{OH})_{3}$ and $\mathrm{ZnHPO}_{3}$ composite that detach form the $\mathrm{Al} / \mathrm{Au} / \mathrm{ZnO}$ anode surface after discharging, inductively coupled plasma mass spectroscopy (ICP-MS) analysis were carried out for trace $\mathrm{Al}$ and $\mathrm{Zn}$ element in $10 \%$ nitric acid. It was found that $\mathrm{Al}$ was the major constituent of the byproduct composite as shown in Figure $2 \mathrm{C}$ and this may likely be attributed to the enhanced hydrogen evolution from the corrosion of metallic $\mathrm{Al}$ in physiological saline buffer.

\section{Effect of Corrosion of $A l$ anode and the reducing capability of hydrogen}

To evaluate the effect of the pitting corrosion of the $\mathrm{Al} / \mathrm{Au} / \mathrm{ZnO}$ anode in aiding the use of hydrogen as a reductant, cyclic voltammetry $(\mathrm{CV})$ was employed to oxidize water in phosphate electrolyte at extremely high potentials to generate oxygen at the bare $\mathrm{Al}$ and $\mathrm{Al} / \mathrm{Au} / \mathrm{ZnO}$ anodes. Results of the electrochemical measurements of the currents of the anode are shown in Figure 3A. At high potential, the oxidation of water in air-saturated phosphate buffer resulted in the highest oxidation current density $\left(5.1 \mu \mathrm{Acm}^{-2}\right)$ and a relatively low cathodic current density of $-0.15 \mu \mathrm{Acm}^{-2}$ in the presence of $\mathrm{Al} / \mathrm{Au} / \mathrm{ZnO}$. A pair of well-defined redox peaks was observed at ca. $1.7 \mathrm{~V}$ and $0.48 \mathrm{~V}$ vs. $\mathrm{Ag} / \mathrm{AgCl}$ for the oxidation of water and reduction of oxygen, respectively. The $\mathrm{Al} / \mathrm{Au}$ anode exhibited electrocatalytic activity towards the oxidation of water at high potentials with a current density of $3.66 \mu \mathrm{Acm}^{-2}$ and cathodic current density of $-0.54 \mu \mathrm{Acm}^{-2}$, whereas the Al anode exhibited insignificant electroactivity. These results reveal that $\mathrm{ZnO}$ modifier exhibit electron transfer activity that can enhance the pitting corrosion of the Al. Thereby, Al anode will use as the base line anode due to its insignificant electroactivity.

When metallic $\mathrm{Al}$ is in contact with water, the mobile species, water molecules (or $\mathrm{OH}^{-}$ions) react with the $\mathrm{Al}$, resulting in hydrogen evolution [36]. In fact, both hydrogen and metallic Al are possible reductant species in this reaction system. Figure $3 \mathrm{~B}$ shows the $\mathrm{CV}$ of the BuckyPaper in $\mathrm{H}_{2}$-saturated environment and the scan reveals that hydrogen is effective in reducing phosphate in the phosphate electrolyte. Previously mentioned above, the $\mathrm{H}_{2} \mathrm{PO}_{4}{ }^{-}$can adsorb on the electrodes in the early stages of corrosion and be reduced to $\mathrm{HPO}_{3}{ }^{2-}$ ions that in turn react with the solid phase surfaces of $\mathrm{ZnO}$ nanocrystals by adsorption and precipitation. Thus, the hydrogen diffuses to the top of the $\mathrm{Al}(\mathrm{OH})_{3}$ film and facilitate the reduction of $\mathrm{H}_{2} \mathrm{PO}_{4}{ }^{-}$in phosphate electrolyte at a formal potential of $-0.250 \mathrm{~V}$ vs. $\mathrm{Ag} / \mathrm{AgCl}$. This may suggest that this reduction does not acquire the electrons released from the oxidation of $\mathrm{Al}$ beneath the nonconductive $\mathrm{Al}_{2} \mathrm{O}_{3}$ layer, but from the oxidation reaction (2) of hydrogen on the top of the oxide film.

$$
H_{2} \rightarrow 2 H^{+}+2 e^{-}
$$

The hydrogen produced as a result of the pitting corrosion of $\mathrm{Al}$ cannot reduce the $\mathrm{Al}(\mathrm{OH})_{3}$ because of its very low standard reduction potential of $\mathrm{E}_{\mathrm{Al}(\mathrm{OH}) 3 / \mathrm{Al}}^{\circ}=-2.31 \mathrm{~V}$. Thus, the electrons released from the oxidation reaction on top of the $\mathrm{Al}(\mathrm{OH})_{3}$ film recombines with the $\mathrm{H}_{2} \mathrm{PO}_{4}^{-}$ions on the surface of the cathode to reduce it to $\mathrm{HPO}_{3}{ }^{2-}$ ions. These ions then react with $\mathrm{Zn}^{2+}$ release from $\mathrm{ZnO}$ nanocrystals and the adsorption and precipitation of $\mathrm{HPO}_{3}{ }^{2-}$ results in the formation of $\mathrm{Al}(\mathrm{OH})_{3}$ and $\mathrm{ZnHPO}_{3}$ composite. This composite detach from the Al substrate when the oxide below is broken and new oxide forms on top of the Al. Hence, the Al activated by pitting corrosion has the reducing capability of hydrogen, which is used to reduce $\mathrm{H}_{2} \mathrm{PO}_{4}{ }^{-}$as shown in the following cell reaction (3) [48].

$$
\mathrm{H}_{2} \mathrm{PO}_{4}^{-}+\mathrm{H}^{+}+2 e^{-} \rightarrow \mathrm{HPO}_{3}^{2-}+\mathrm{H}_{2} \mathrm{O}
$$

at the cathode to generate $\mathrm{HPO}_{3}{ }^{2-}$ ions. This further suggests that the dissolution of $\mathrm{ZnO}$ in phosphate results in the release of $\mathrm{OH}^{-}$ions by the replacement of the $\mathrm{OH}^{-}$ions with the reduction product, $\mathrm{HPO}_{3}{ }^{2-}$ ions, to form $\mathrm{ZnHPO}_{3}$, leading to the decrease in $\mathrm{H}^{+}$concentration in the solution. This increased the $\mathrm{pH}$ of the phosphate electrolyte to 8.2 upon discharging in phosphate electrolyte and further lead to the formation of $\mathrm{Al}(\mathrm{OH})_{3}$ and $\mathrm{ZnHPO}_{3}$ composite. This reaction is beneficial in connection with corrosion protection of metallic electrodes under physiological condition, where it may reduce the current and extend the life of the anode.

\section{Complete hybrid cell supplied with phosphate rich electrolyte}

Results of the potentiostatic polarization curves obtained with the bare $\mathrm{Al}$ and $\mathrm{Al} / \mathrm{Au} / \mathrm{ZnO}$ anodes are shown in Figure 4 . The bare $\mathrm{Al}$ anode show nearly no catalytically activity because the current densities were less than $1 \mu \mathrm{A} \mathrm{cm}$. This indicates that the $\mathrm{Al}$ surfaces is relatively smooth and does not have an electroactive species bound and electrically connected with the electrode. Whereas, the growth of $\mathrm{ZnO}$ nanocrystals on the surface of $\mathrm{Al} / \mathrm{Au}$ greatly enhances the surface roughness of the electrode. All these indicates that the $\mathrm{Al} / \mathrm{Au}$ electrode modified with $\mathrm{ZnO}$ generates greater current density than the bare $\mathrm{Al}$ surface because of the electrical connection established between the $\mathrm{ZnO}$ and the metallic $\mathrm{Al}$ surface.

The performance of the $\mathrm{Al} / \mathrm{Au} / \mathrm{ZnO}$ anode was evaluated with BuckeyPaper as the cathodic electrode in a single compartment cell configuration at different external loads (1 $\mathrm{k} \Omega$ to $1 \mathrm{M} \Omega$ ) in phosphate buffer and physiological saline buffer in air-saturated environment. This membraneless cell is especially unique with respect to hybrid cells as most operate using a membrane in order to isolate the anode and cathode during cell operation. The generated electrons from the anode flow to the cathode through the external load circuit. The reaction mechanism, current density-voltage and power density-current characteristics for phosphate buffer and physiological saline buffer are presented in Figure 5. The observed open circuit voltage and power density of the phosphate buffer cell were $0.810 \mathrm{~V}$ and $0.225 \mathrm{~mW} \mathrm{~cm} \mathrm{~cm}^{-2}$ at a current density of $1.36 \mathrm{~mA}$ $\mathrm{cm}^{-2}$, respectively. These values are lower than the expected and this may be a result of the byproduct absorptivity at the anode, which inhibits the anode performance. Consequently, the maximum power density was increased eightfold to $1.77 \mathrm{~mW} \mathrm{~cm}^{-2}$ at a current density of $11.95 \mathrm{~mA} \mathrm{~cm}^{-2}$ when operating in physiological saline buffer cell. The higher current density observed in the presence of physiological saline buffer is attributed to the $\mathrm{Cl}^{-}$ions in physiological saline buffer, which can readily wear out the oxide film and readily access the $\mathrm{Al}$, thereby inducing a greater degree of pitting corrosion of $\mathrm{Al}$. The current-producing reaction continues until no more $\mathrm{Al}$ sites are available for pitting, thus no current flow through the system.

Control experiments using bare $\mathrm{Al}$ as the anode in phosphate buffer, resulted in no significant power output $\left.(0.24 \mu \mathrm{W} \mathrm{cm})^{-2}\right)$. Here we have demonstrated that the cell efficiency depends on the pitting corrosion of $\mathrm{Al}$ and the cell environment. 
These power and current densities are much higher than those reported for glucose biofuel cell based on bilirubin oxidase and glucose oxidase derived from Aspergillus niger [49-51], enzyme-free glucose fuel cell [52] and glucose dehydrogenase biofuel cell [11]. Also, we have demonstrated a simple "green" method of using Al foil modified with $\mathrm{ZnO}$ as a reductant to the phosphate electrolyte and physiological saline electrolyte with $\mathrm{Cl}^{-}$ions at room temperature to develop a single compartment hybrid $\mathrm{Al} /$ phosphate cell that can generate enough power that can be used for powering bio-implantable electronic devices or low powered electronic devices.

Figure 6 shows the stability of the cell performance operating in physiological saline buffer and $20 \mathrm{mM}$ phosphate buffer under airsaturated conditions. Polarization curves of duplicate cells were obtained once a day for 2.5 weeks. After day 8 , the buffers were exchanged every two days (indicated with $\downarrow$ ). An increase in current were observed as a result of the exchange of the spent physiological saline or phosphate buffer electrolyte for a fresh electrolyte. The results show good stability of the current density over the 2.5 weeks in physiological saline with approximately $28 \%$ drop in activity on day 9 , where $100 \%$ activity is the current density at an external load of $3 \mathrm{k} \Omega$ at day 1 . A $22 \%$ drop in activity was observed for the phosphate buffer cell at day 9. However, the phosphate buffer cell illustrates a limited lifetime of the cell, whereas the physiological saline buffer cell exhibited an overall stable current density profile. This stability in the profile could be attributed to the enhanced access to the active sites available for pitting via $\mathrm{Cl}$ - ions in physiological saline buffer.

\section{Experimental}

\section{Materials}

Zinc chloride (99.99\%), triethenamine (TEA, 99.99\%), and all chemical reagents were purchased from Sigma-Aldrich and all supplementary chemicals were of analytical grades and used without further purification. All solutions were prepared with $18.2 \mathrm{M} \Omega \mathrm{cm}$ Milli-Q water.

\section{Electrode preparation}

The $\mathrm{Al} / \mathrm{Au} / \mathrm{ZnO}$ electrode fabrication was previously reported [53]. Briefly, pure aluminium foil (Alfa Aesar, 99.9999\%, $250 \mu \mathrm{m}$ thick) was cut into pieces of approximately $1 \mathrm{~cm} \times 0.5 \mathrm{~cm}$ and used as support substrates for the deposition of a thin film of gold and the subsequent hydrothermal growth of $\mathrm{ZnO}$ seed layers via a simple sol-gel process under mild conditions. Briefly, the $\mathrm{ZnO}$ precursors were prepared using zinc chloride and propanol. Triethenamine was added to the precursor solution to produce a final $0.1 \mathrm{M}$ homogeneous $\mathrm{ZnO}$ nanosol, which was then aged. The $\mathrm{ZnO}$ seed layers were established on the Al substrate as a modifier via multiple dip-coating and annealing methods to form a thick layer of seeds. The resulting $\mathrm{Al} / \mathrm{Au} / \mathrm{ZnO}$ electrode was rinsed and dried overnight, in a desiccator. Recently, carbon-based cathodes, such as BuckyPaper has been used in lithium air cells [54]. Thus, BuckyPaper composed of compressed multiwalled carbon nanotubes (NanoTechLabs, Yadkinville, NC) was used as the cathode material (geometric area $0.25 \mathrm{~cm}^{2}$ ).

\section{Electrochemical Instrumentation and procedures}

Electrochemical characterizations were conducted on BASi potentiostat/galvanostats EC Epsilon. All experiments were carried out at room temperature $\left(25 \pm 1{ }^{\circ} \mathrm{C}\right)$. The electrochemical experiments were performed in a conventional three-electrode cell with the exception of the fuel cell characterizations. The $\mathrm{Ag} / \mathrm{AgCl}$ $\left(\mathrm{KCl}_{\text {sat }}\right)$ and platinum wire were used as the reference and counter electrode, respectively. The working buffer solution was $20 \mathrm{mM}$ phosphate buffer. All potentials referenced in the present work are measured against $\mathrm{Ag} / \mathrm{AgCl}$ reference electrode. Cyclic voltammetry were conducted with scan rates of $20 \mathrm{mV} \mathrm{s}^{-1}$ in air-saturated environment. The anode was further characterized using potentiostatic polarization curves generated by applying a series of potentials to the anode.

The cell characterizations were carried out in phosphate buffer $(\mathrm{pH}$ 7.4) and physiological saline buffer ( $\mathrm{pH} 7.4,0.137 \mathrm{NaCl}, 20 \mathrm{mM}$ phosphate) in air-saturated environment. The cell consisted of the $\mathrm{Al} / \mathrm{Au} / \mathrm{ZnO}$ anode and BuckyPaper cathode in the single compartment cell. The polarization curves for the cell was obtained from the use of a series of external loads ( $1 \mathrm{M} \Omega$ to $1 \mathrm{k} \Omega$ ). The power density was obtained for the cell. Current densities were calculated using geometrical area of electrode.

After discharging the anode in the phosphate rich electrolyte, the morphology and structural characteristics of bare $\mathrm{Al}$ anode and asfabricated $\mathrm{ZnO}$ modified $\mathrm{Al}$ anode $(\mathrm{Al} / \mathrm{Au} / \mathrm{ZnO})$ were characterized by atomic force microscopy (AFM) using an Agilent 5500 Scanning Probe Microscope/ PicoView Software (Agilent Technologies, USA) and field-emission scanning electron microscopy (SEM, Hitachi SU70 ) at $10 \mathrm{kV}$. The surface roughness root mean square (RMS) values were measured over $2 \times 2 \mu \mathrm{m}^{2}$ areas for all samples. The elemental analysis of the byproduct were determined using X-ray photoelectron spectroscopy (XPS: Kratos Axis 165) at $10^{-8}$ to $10^{-9}$ Torr for the characterization of the $\mathrm{Al}(\mathrm{OH})_{3}$ and $\mathrm{ZnHPO}_{3}$ composite high resolution scans of the $\mathrm{Al} 1 s, \mathrm{Al} 2 p, \mathrm{P} 2 p, \mathrm{Zn} 2 p, \mathrm{O} 1 s$ and $\mathrm{C} 1 s$ peaks. ${ }^{1} \mathrm{H}$ NMR and ${ }^{31} \mathrm{P}$ NMR measurements were performed on JEOL ECX $400 \mathrm{MHz}$ NMR spectrometer. The trace Al, Zn and K elements in the byproduct were detected using inductively coupled plasma mass spectrometer (ICP-MS, PerkinElmer NexIon 300D with autosampler).

\section{Conclusions}

Here we present the activation of $\mathrm{Al}$ via $\mathrm{ZnO}$ nanocrystal modifier on $\mathrm{Al} / \mathrm{Au}$ support electrode. Using hydrothermal growth and $\mathrm{ZnO}$ nanosol process, we demonstrate the activation of $\mathrm{Al}$ in the presence of phosphate rich electrolyte by inducing pitting corrosion on the surface of $\mathrm{Al}$, which in turn accelerate the mobile defect species in the $\mathrm{Al}_{2} \mathrm{O}_{3}$ layer to sustain a continuous reaction with the water in the electrolyte. These results led to the use of $\mathrm{Al} / \mathrm{Au} / \mathrm{ZnO}$ as anodic platform combine with BuckyPaper cathode to realize a membraneless hybrid cell. We achieved an open-circuit voltage of $0.751 \mathrm{~V}$ and delivered a maximum power density of $1.77 \mathrm{~mW} \mathrm{~cm}^{-2}$ at a current density of $11.95 \mathrm{~mA} \mathrm{~cm}^{-2}$ in physiological saline buffer. The $\mathrm{Al}$ with $\mathrm{ZnO}$ modifier as a simple anodic material can serve as a good alternative to enzyme and/ or mediator based anodes because of its simplicity and it addresses the issues with the lack of efficient direct electron transfer due to large distance between the electrode surface and the enzyme active center, and limited number of enzyme molecules that can be electrically coupled to the electrode. However, further optimization of the reaction conditions could help realize further control of the open circuit voltage, current and power densities. A special feature of the constructed hybrid cell is that it generates hydrogen gas, high power output and provides clean electric energy production at room temperature and in physiological 
saline buffer, thereby enabling an inexpensive route to construct a complete hybrid cell systems for bioelectronic devices.

\section{Acknowledgements}

This work was supported by National Science Foundation (Award ECCS-\# 1349603).

\section{References}

1 D. Leech, P. Kavanagh and W. Schuhmann, Electrochim. Acta, 2012, 84, 223.

2 M. H. Osman, A. A. Shah and F. C. Walsh, Biosens. Bioelectron., 2011, 26, 3087.

3 E.H. Yu and K. Scott, Energies, 2010, 3, 23.

4 M.J. Cooney, V. Svoboda, C. Lau, G. Martin and S.D. Minteer, Energy Environmental Science, 2008, 1, 320.

5 R. A. Bullen, T. C. Arnot, J. B. Lakeman and F. C. Walsh, Biosens. Bioelectron., 2006, 21, 2015.

6 J.A. Cracknell, K.A. Vincent and F.A. Armstrong, Chemical Reviews, 2008, 108, 2439.

7 H. Aurélien, S. Karine, T. Sophie and K. Boniface, Biofuel's Engineering Process Technology, 2011, 467.

8 K. MacVittie, J. Halámek, L. Halámkova, M. Southcott, W.D. Jemison, R. Lobel and E. Katz, Energy Environmental Science, 2013, 6, 81.

9 G. Slaughter and K. Amoah, Journal of Biosensors \& Bioelectronics, 2012, 3, 1.

10 A. Zebda, S. Cosnier, J.-P. Alcaraz, M. Holzinger, A. Le Goff, C. Gondran, F. Boucher, F. Giroud, K. Gorgy, H. Lamraoui and P. Cinquin, Scientific Reports, 2013, 3, 1516.

11 L. Halámková, J. Halámek, V. Bocharova, A. Szczupak, L. Alfonta and E. Katz, Journal of the American Chemical Society, 2012, 134, 5040.

12 M. Rasmussen, R.E. Ritzmann, I. Lee, A.J. Pollack and D. Scherson, Journal of the American Chemical Society, 2012, 134, 1458.

13 M. Zayats, E. Katz and I. Willner, I. J. Am. Chem. Soc., 2002, 124, 14724.

14 C. W. N. Villarrubia, R.A. Rinćon, V.K. Radhakrishnan, V. Davis and P. Atanassov, ACS Appl. Mater. Interfaces, 2011, 20113, 2402.

15 J. Hwang, M.G. Choi, S. Eor, S.-K. Chang, Inorganic Chemistry, 2012, 51, 1634.

16 M. Jönsson-Niedziolka, A. Kaminska, M. Opallo, Electrochimica Acta, 2010, 55, 8744.

17 R.P. Ramasamy, H.R. Luckarift, D.M. Ivnitski, P.B. Atanassov, G.R. Johnson, Chemical Communications, 2010, 46, 6045 .

18 S.A. Merchant, M.T. Meredith, T.O. Tran, D.B. Brunski, M.B. Johnson, D.T. Glatzhofer, D.W. Schmidtke, Journal of Physical Chemistry C,2010, 114, 11627.

19 C. Vargel, "Corrosion of Aluminium," Elsevier, 2004.

20 Q. Li, B.J. Niels, J Power Sources, 2002, 110, 1.

21 J. Bernard, M. Chatenet, F. Dalard. Electrochimica Acta 2006, 52, 86

22 S. Gudic, J. Radosevic, K.M. Smoljko. Electrochimica Acta, 2005, 50, 5624.

23 Z. Zhang, C. Zuo, Z. Liu, Y. Yu, Y. Zuo, Y. Song. Journal of Power Sources, 2014, 251, 470.
24 A.E. Segneanu, I. Grozescu, I. Balcu, N. Vlatanescu, P. Sfirloaga. Practical and Theoretical Aspects, 2012.

25 I. Smoljko, S. Gudić, N. Kuzmanić, M. Kliškić. J. Appl Electrochem, 2012, 42, 969.

26 S. Gudic, I. Smoljko, M. Kliškić. Materials Chemistry and Physics, 2010, 121, 561

27 H.J.W. Lenderink, M.V.D. Linden, J.H.W. De Wit. Electrochim. Acta 1993, 38, 1989.

28 E. McCafferty. Corrosion Science, 2003, 45, 1421.

29 M.A. Amin, S.S. Abd el Rehim, A.S. El-Lithy. Corrosion Science. 2010, 52, 3099.

30 L. Wang, W. Wang, G. Yang, D. Liu, J. Xuan, H. Wang, M.K.H. Leung, F. Liu. Journal of Hydrogen Energy, 2013, 38, 14801 .

31 A. Kindler, L. Matthies. SPIE Proceedings, 2014, 90831.

32 M. Armand, J.M. Tarascon. Nature, 2008, 451, 652.

33 R. Revel, T. Audichon, S. Gonzalez. 2014, 272, 415.

34 J.S. Lee, S. Tai Kim, R. Cao, N.S. Choi, M. Liu, K.T. Lee, J. Cho. Adv. Energy Materials, 2011, 1, 34.

35 D.R. Egan, C.P. De León, R.J.K. Wood, R.L. Jones, K.R. Stokes, F.C. Walsh. Journal of Power Sources, 2013, 236, 293.

36 B.C. Bunker, G.C. Nelson, K.R. Zavadil, J.C. Barbour, F.D. Wall, J.P. Sullivan, et al. J Phys Chem B 2002, 106, 4705.

37 M. Digne, P. Sautet, P. Raybaud, P. Euzen, H. Toulhoat, E. Artacho. J. Phys Chem B 2002, 106, 5155.

38 A.A. Mazhar, W.A. Badawy, M.M. Abou-Romia. Surface and Coatings Technology 1986, 29, 335.

39 Lv. J. Zhang, S. Luo, L. Han, W. Zhang, J. Yang, K. Christie, P. Environmental Science \& Technology 2012, 45, 7215.

40 M. Sukhendu, S. Natarajan. Inorganic chemistry 2008, 47, 5304.

41 N.A. Curry, D.W Jones. Journal of the Chemical Society A, $1971,3725$.

42 X.Y. Xue, M. Kanzaki. Journal of Physical Chemistry B, 2007, 11, 13156.

43 K. Komatsu, A. Sano, K. Momma, E. Ohtani, Y. Kudoh. Zeitschrift fuer Kristallographie, 2007, 222, 13.

44 H. Saalfeld, M. Wedde. Zeitschrift Fur Kristallographie, 1974, 139S, 129.

45 R.E. Mishler II, A.V. Biradar, C.T. Duncan, E.A. Schiff, T. Asefa. Chemical Communications, 2009, 41, 6201.

46 M. Pelavin, D. N. Hendrickson, J. M. Hollander, W. L. Jolly, J. Phys. Chem., 1970, 74, 1116.

47 B. V. Crist, Handbook of Monochromatic XPS Spectra, Vol. 2, XPS International Inc., 2005.

48 R.M. De Graaf, R. M., A.W. Schwartz. Origins of Life and Evolution of the Biosphere, 2000, 30, 405.

49 W. Shin, J. Lee, Y. Kim, H. Steinfink, A. Heller. J Am Chem Soc 2005, 127, 14590.

50 R. Kontani, S. Tsujimura, K. Kano, Bioelectrochemistry, 2009, 76, 10.

51 V. Soukharev, N. Mano, and A. Heller. J Am Chem Soc, 126, $2004,8368$.

52 V. Oncescu and D. Erickson, Journal of Power Sources, 2011, 196, 9169.

53 G. Slaughter, J. Sunday, Journal of Power Sources, 2014, 261, 332.

54 G.Q. Zhang. Journal of Electrochemical Society, 2010, 157, A953. 


\section{FIGURE LEGENDS:}
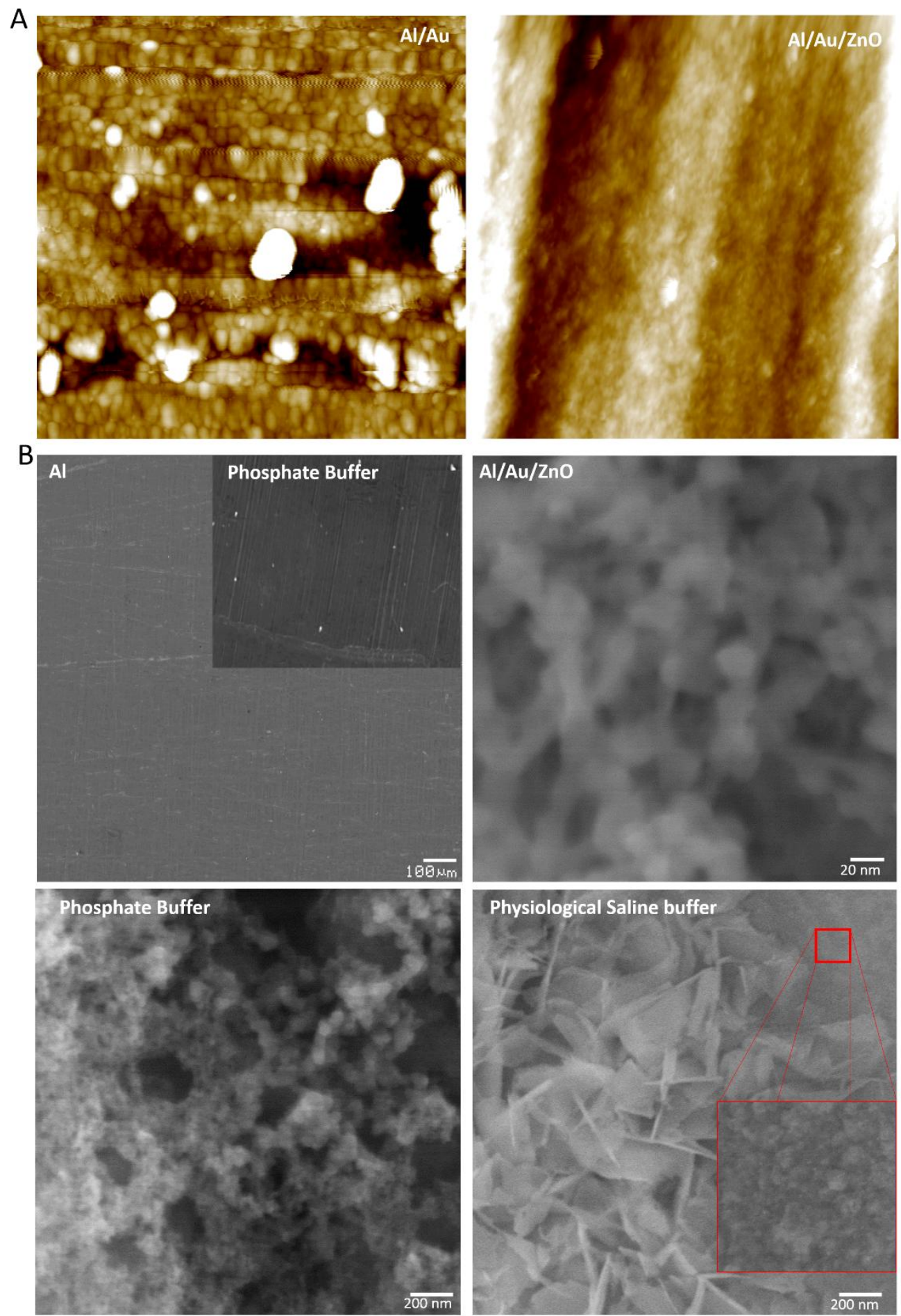

Figure 1. Representative surface characterization of $\mathrm{Al} / \mathrm{Au} / \mathrm{ZnO}$ anode. (A) AFM micrograph $(2 \mu \mathrm{m} \times 2 \mu \mathrm{m})$ of $\mathrm{Al} / \mathrm{Au}$ and $\mathrm{Al} / \mathrm{Au} / \mathrm{ZnO}$. (B) SEM micrograph of bare $\mathrm{Al}$ and $\mathrm{Al} / \mathrm{Au} / \mathrm{ZnO}$ anode after discharging in phosphate buffer and physiological saline buffer. 


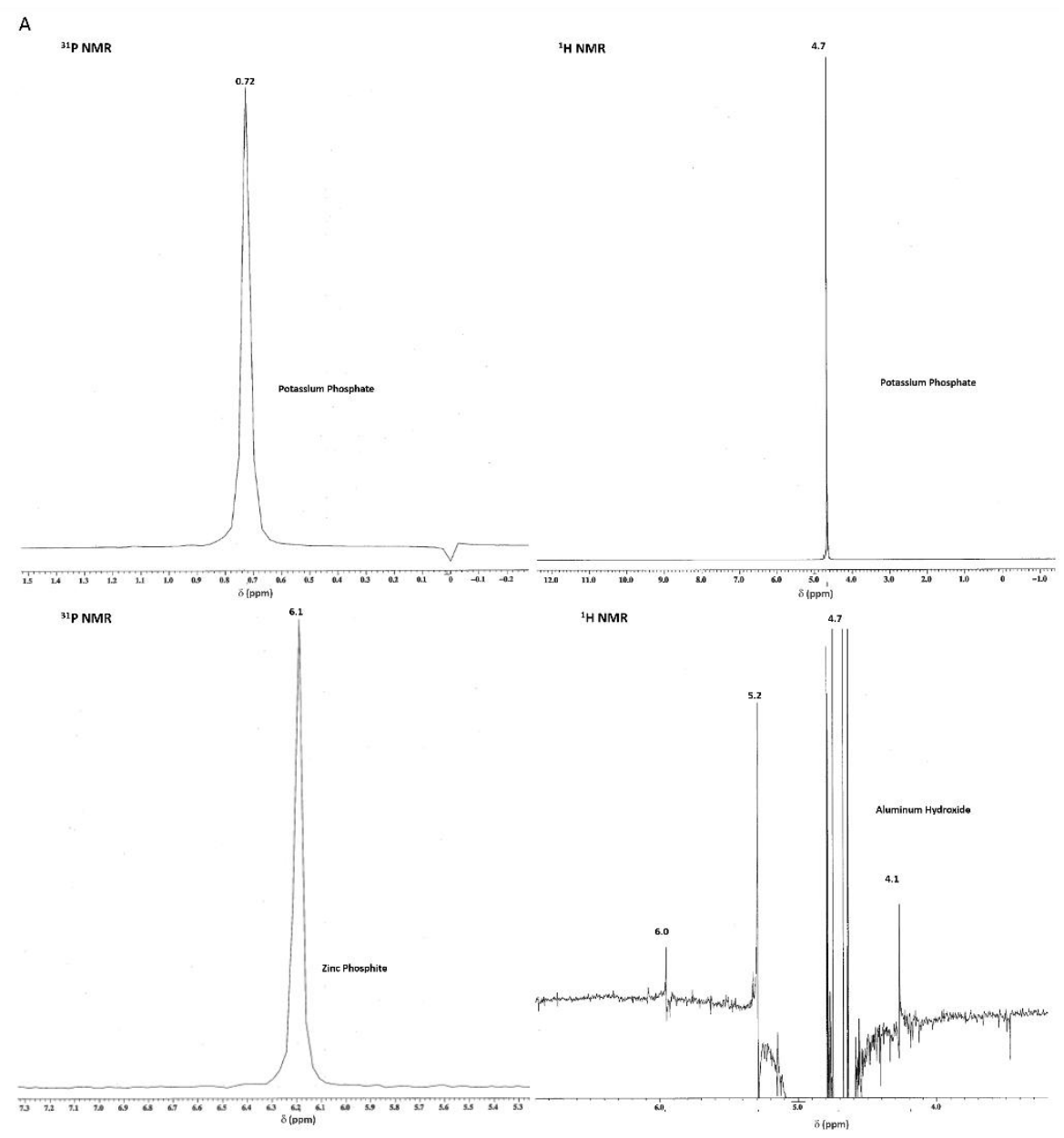

B

$\mathrm{C}$
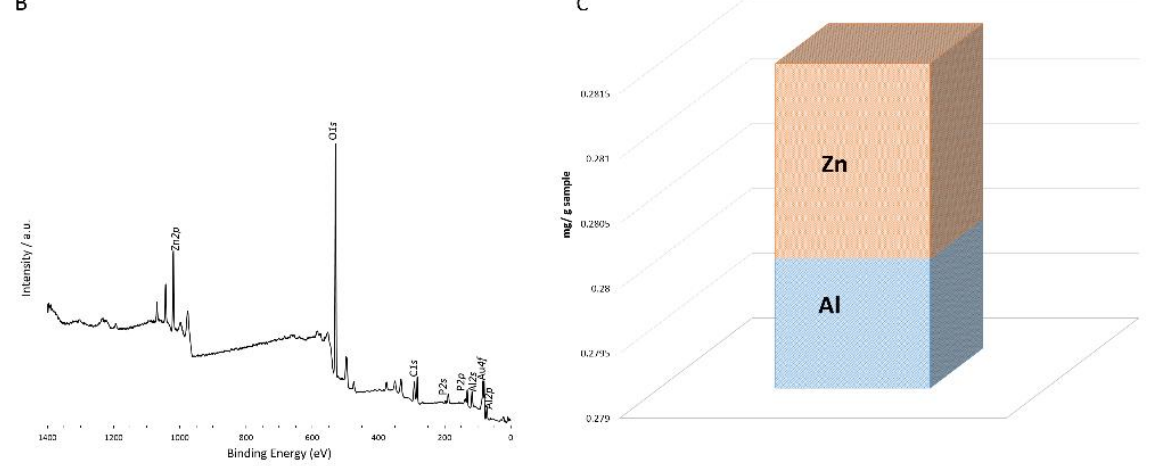

Figure 2. Reaction byproduct characterization: (A) ${ }^{31} \mathrm{P}$ NMR and ${ }^{1} \mathrm{H}$ NMR spectra of potassium phosphate buffer and $\mathrm{Al}(\mathrm{OH})_{3}$ and $\mathrm{ZnHPO}{ }_{3}$ composite; (B) XPS spectra of $\mathrm{ZnHPO}_{3}$ and $\mathrm{Al}(\mathrm{OH})_{3}$ composite after discharging in physiological saline buffer solution; and (C) ICP characterization of trace elements via the dissolution of $\mathrm{Al}$ and $\mathrm{Zn}$ from $\mathrm{Al}(\mathrm{OH})_{3}$ and $\mathrm{ZnHPO}_{3}$ composite. 
A

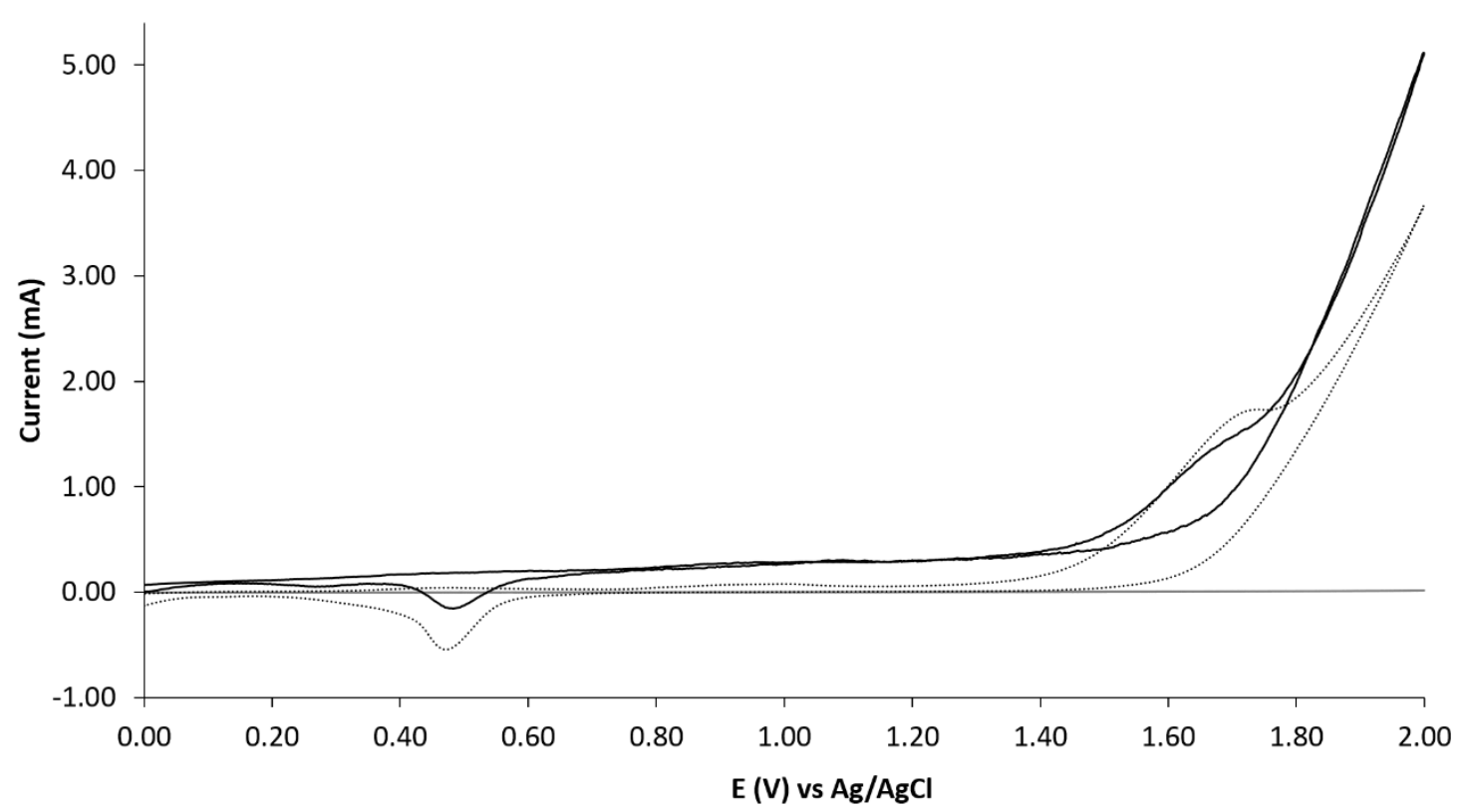

B

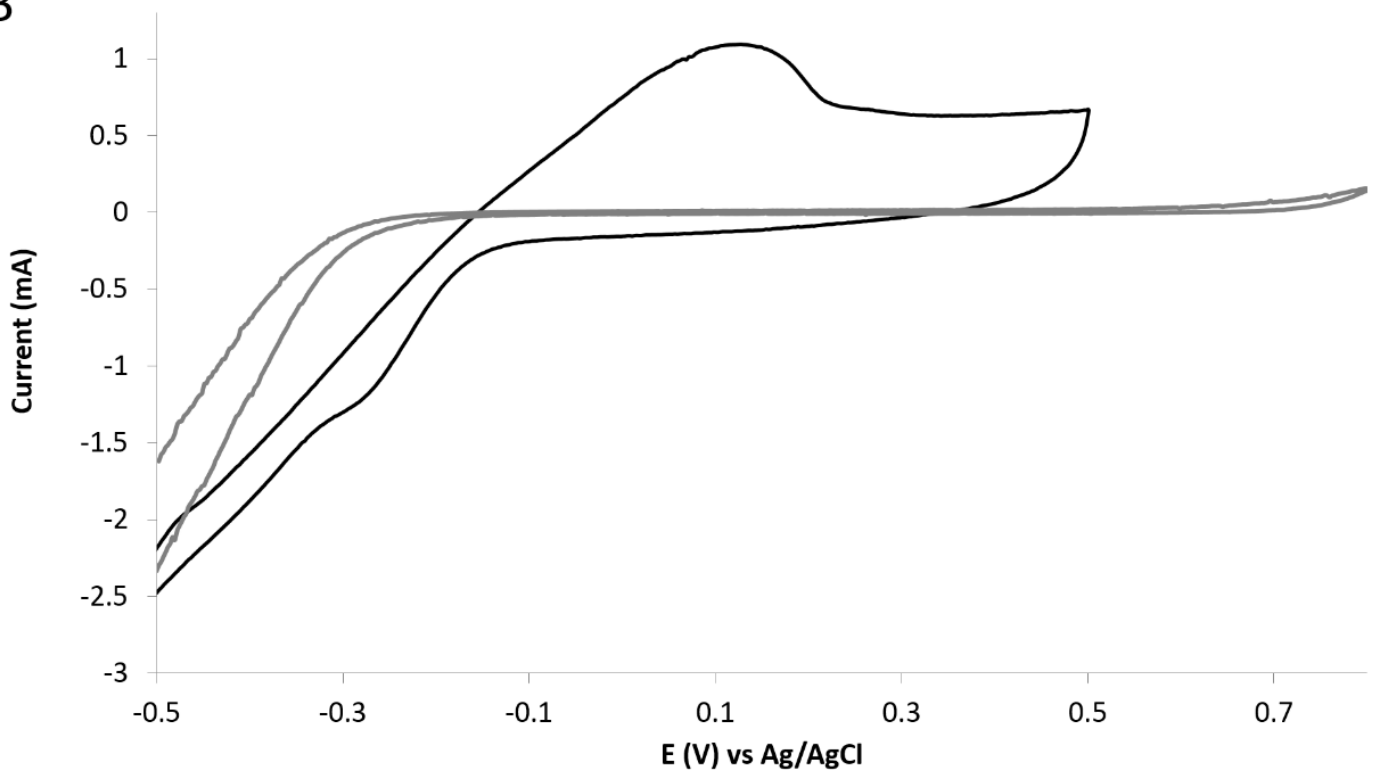

Figure 3. (A) $\mathrm{CV}$ curves in phosphate electrolyte $(\mathrm{pH}=7.4)$ on $\mathrm{ZnO}$ modified $\mathrm{Al}(\mathrm{Al} / \mathrm{Au} / \mathrm{ZnO})$ (black line), bare $\mathrm{Al}$ (grey line), and $\mathrm{Al} / \mathrm{Au}$ (dotted line) under air-saturated condition. (B) CV curves of BuckyPaper cathode in phosphate electrolyte under $\mathrm{H}_{2}-\mathrm{saturated}$ (black line) and under $\mathrm{O}_{2}$-saturated (grey line) conditions. Scan rate: $20 \mathrm{mV} \mathrm{s}^{-1}$. 


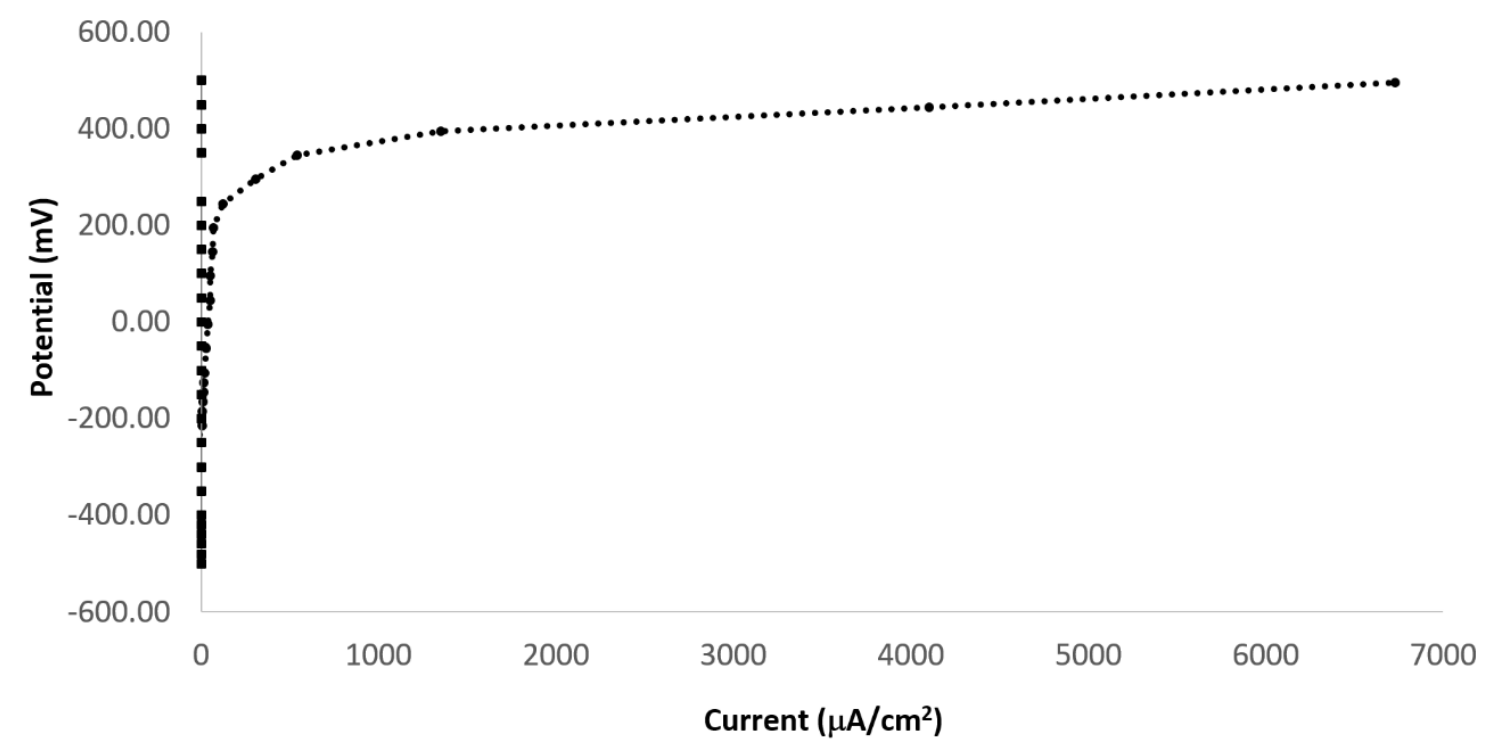

Figure 4. Representative potentiostatic polarization curves of $\mathrm{Al}(\boldsymbol{\bullet})$ and $\mathrm{Al} / \mathrm{Au} / \mathrm{ZnO}(\bullet)$ electrodes.
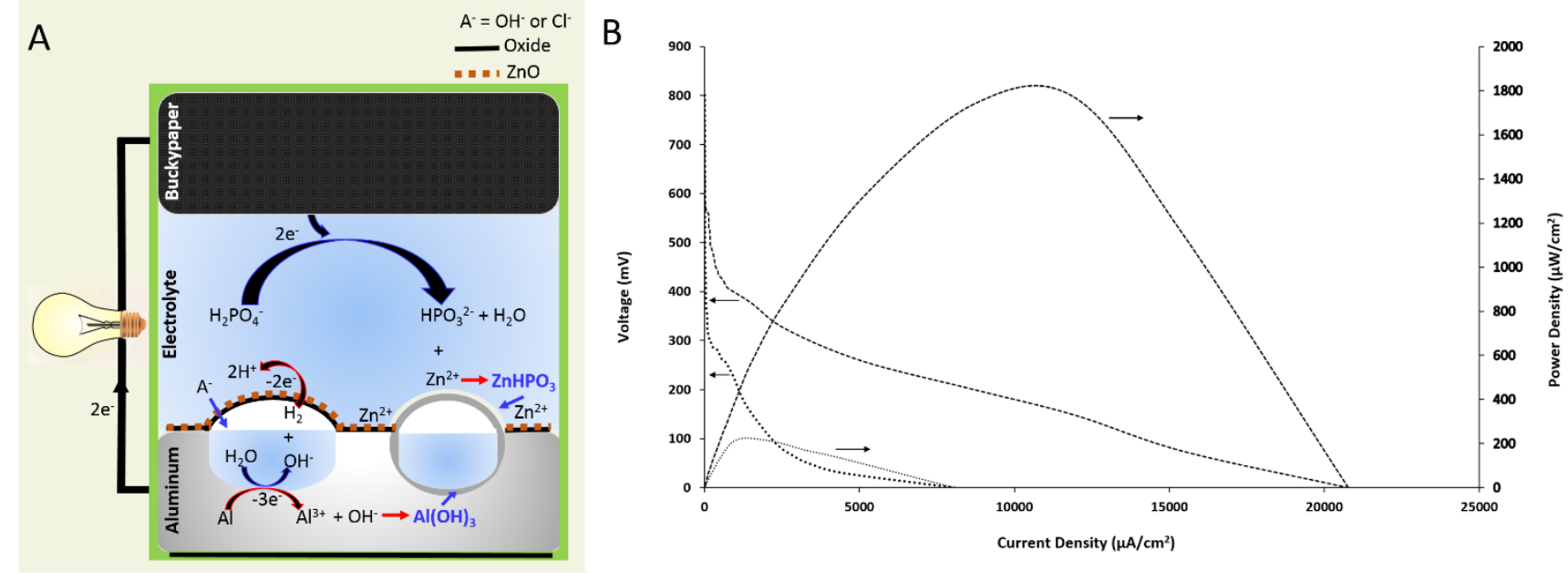

Figure 5. (A) Schematic illustrating the reaction mechanism and (B) Current density-voltage and power density-current characteristics for $\mathrm{Al} / \mathrm{Au} / \mathrm{ZnO}$ at the anode and $\mathrm{BP}$ at the cathode, operating in phosphate buffer $(\bullet)$ and in physiological saline buffer (--) in air-saturated environment. 


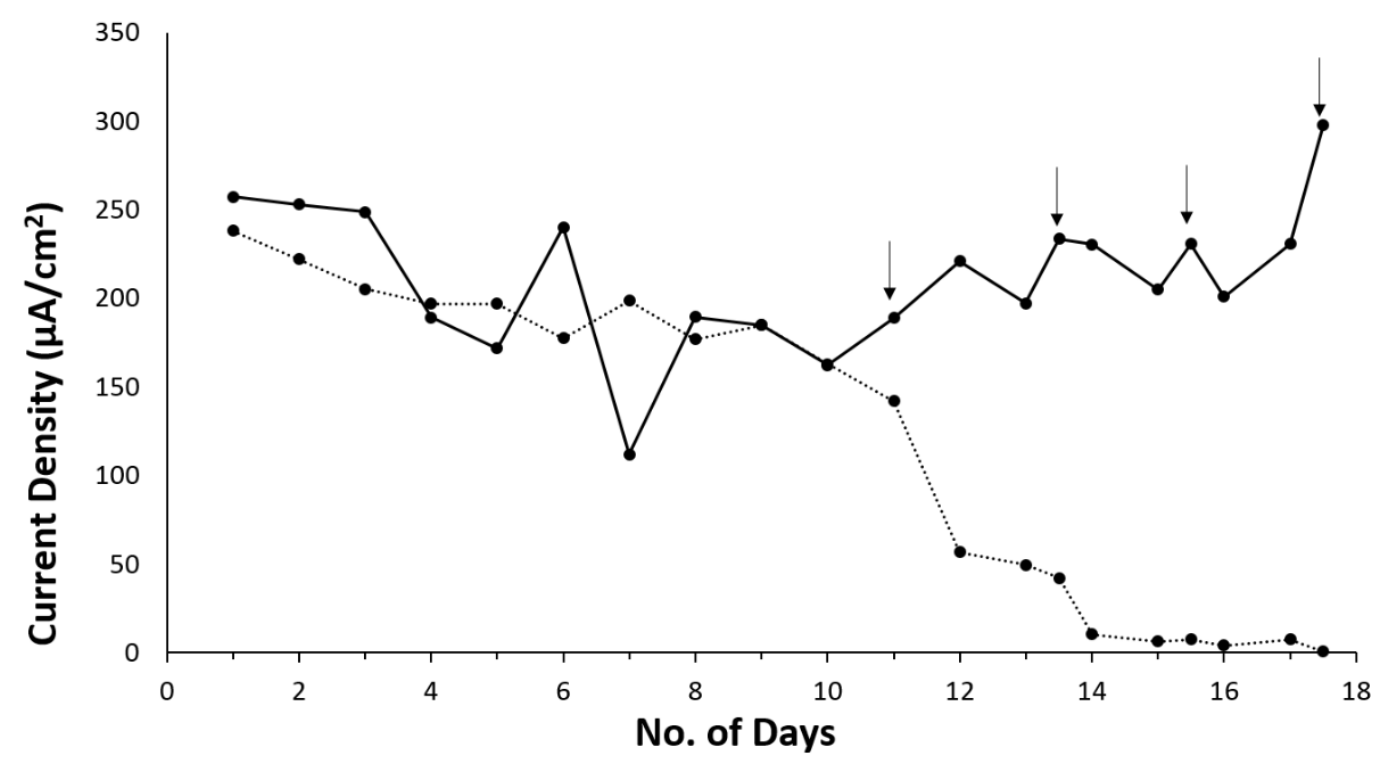

Figure 6. Stability of the cell performance operating in physiological saline buffer $(-)$ and $20 \mathrm{mM}$ phosphate buffer ( ( .......) under airsaturated conditions. The buffers were exchanged every two days following day 8 (indicated with $\downarrow$ ). The current densities were taken at a constant load of $3 \mathrm{k} \Omega$.
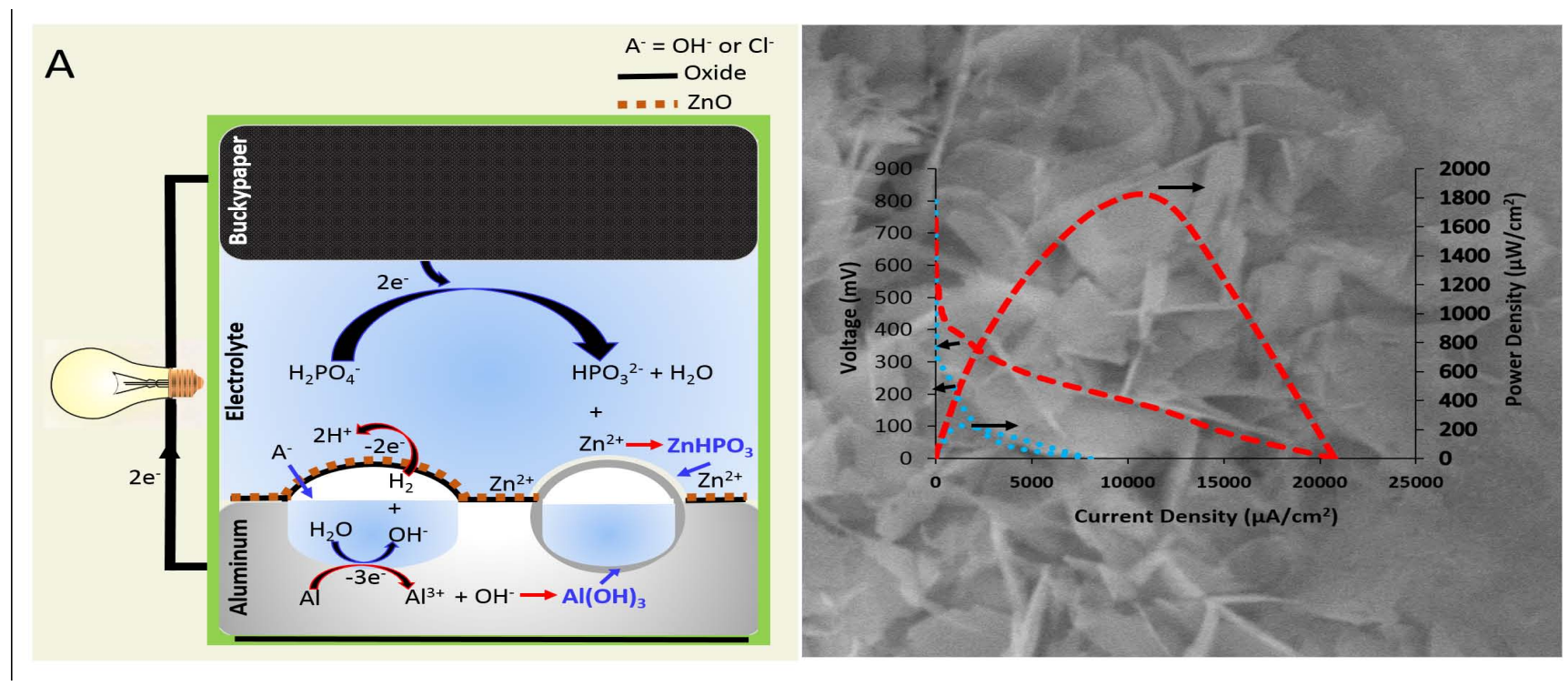

\section{Graphical Abstract}

